\title{
Homoseksualitas Masa Kini: Suatu Tinjauan Menurut Etika Kristen
}

\author{
Suzanna Hilaria Halim* \\ *Penulis adalah mahasiswa M.Th. Konseling di STT SAAT Malang. \\ Email: suzanna_hilaria@yahoo.com
}

\begin{abstract}
Abstrak: Homoseksualitas kini tidak lagi hanya dipahami sebagai bentuk perilaku melainkan sebagai suatu bentuk orientasi seksual yang muncul di luar kehendak manusia. Implikasinya, homoseksual dianggap sebagai suatu hal yang wajar dan tidak berdosa. Evaluasi terhadap konsep ini dijelaskan dari sudut pandang biblika dan teologis untuk memberikan jawaban terhadap pertanyaan yang sulit mengenai keberdosaan homoseksual.

Kata-kata kunci: Homoseksual, Perilaku, Orientasi, Tanggung Jawab, Dosa

Abstract: Homosexuality, in this day and age, is not understood as a kind of behavior, but as a sexual orientation that emerges out of human identity and is beyond human will. As a result, people consider homosexuality to be a normal lifestyle and do not perceive of it as sinful behaviour. Evaluations, garnered from both biblical and theological perspectives, are examined to answer the complicated questions related to this topic and conclude that homosexuality is sin.
\end{abstract}

Keywords: Homosexuality, Behavior, Orientation, Responsibility, Sin 


\section{Pendahuluan}

Isu homoseksual bukanlah sesuatu yang baru, namun isu ini terus menimbulkan pro dan kontra di kalangan masyarakat. Pada awal abad ke-20, homoseksual dianggap sebagai suatu bentuk penyimpangan kodrat dan masyarakat sering menunjukkan reaksi homophobia yang hebat terhadap kaum homoseksual. ${ }^{1}$ Namun, saat ini tidak sedikit pihak yang mulai menerima homoseksual sebagai preferensi yang normal dalam seksualitas manusia.

Penelitian yang dilakukan terutama dalam bidang psikologi telah memberikan dampak yang besar dalam merumuskan kembali konsep homoseksual. Homoseksual tidak lagi dipahami sebagai aktivitas seksual yang dilakukan oleh sesama jenis namun juga menyangkut kecenderungan untuk menyukai sesama jenis. Sebagai kecenderungan seksual yang timbul dalam diri manusia dengan sendirinya, aktivis homoseksual menyuarakan bahwa homoseksual tidak boleh disebut sebagai penyimpangan dan harus dilihat sebagai ciptaan Allah yang kreatif dalam hal preferensi seksual manusia. Bahkan beberapa sarjana biblika juga memberikan penafsiran baru terhadap ayat-ayat Alkitab yang biasanya dipakai untuk menentang kaum homoseksual. Mereka berpendapat bahwa pada dasarnya Alkitab tidak menentang homoseksual dan homoseksual bukanlah suatu perilaku yang berdosa. ${ }^{2}$

Munculnya penelitian-penelitian dan penafsiran-penafsiran baru mengenai homoseksualitas mengakibatkan timbulnya banyak pertanyaan dalam diri umat Tuhan. Apakah selama

${ }^{1}$ Homophobia adalah ketakutan yang disertai kebencian terhadap kaum homoseksual dan aktivitas-aktivitas homoseksual. Homophobia ini biasanya menimbulkan sikap dan perilaku negatif terhadap kaum homoseksual berupa kekerasan fisik dan penganiayaan. Malcolm Johnson, "Homophobia," dalam The New Dictionary of Pastoral Studies, ed. Wesley Carr et al. (Grand Rapids: Eerdmans, 2002), 156. Untuk reaksi homophobia lih. G. M. Herek, "Homosexuality," dalam Encyclopedia of Psychology, vol.2, ed. ke-2, ed. Raymond J. Corsini (Toronto: John Wiley \& Sons, 1994), 152.

${ }^{2}$ Stanley J. Grenz, Sexual Ethics: An Evangelical Perspective (Louisville:Westminster John Knox, 1990), 228. ini orang-orang Kristen konservatif ternyata telah salah karena menganggap homoseksualitas adalah dosa? Apakah benar bahwa homoseksual pada dirinya sendiri bukanlah sesuatu yang berdosa? Apakah memang benar bahwa Allah yang menciptakan kaum homoseksual? Pertanyaan-pertanyaan ini tentu saja muncul dari kebingungan dan keingintahuan mengenai apa yang benar sesuai dengan standar kebenaran Kristen. Tulisan ini lahir sebagai salah satu usaha untuk menjawab kebingungan dan keingintahuan tersebut.

Tentunya akan sangat berlebihan jika penulis mencoba untuk menjawab semua pertanyaan di atas. Oleh karena itu, melalui tulisan yang singkat ini penulis akan berfokus pada pertanyaan "Apakah sebenarnya homoseksual berdosa di hadapan Tuhan dan salah secara moral?" dan berusaha menjawabnya berdasarkan kebenaran firman Tuhan. Penulis akan mulai dengan melihat homoseksual sesuai dengan konsep zaman modern berdasarkan hasil penelitian sains kemudian menyoroti konsep tersebut dari segi biblika dan teologis. Dari pemahaman homoseksual secara biblika dan teologis, penulis akan berusaha memberikan jawaban sesuai dengan pertanyaan yang diajukan di atas.

\section{Konsep Homoseksualitas Zaman Modern}

Isu homoseksual bukanlah isu yang baru ada pada zaman modern. Sejak zaman kuno telah ditemukan banyak sekali jejak homoseksualitas dalam kehidupan masyarakat. Namun, ada perbedaan antara homoseksualitas di zaman kuno dengan homoseksualitas di zaman modern. Pada zaman kuno, homoseksualitas dilihat sebagai aktivitas ${ }^{3}$ yang banyak ditemukan dalam ritual agama dan budaya. ${ }^{4}$

\footnotetext{
${ }^{3}$ Yang dimaksud dengan aktivitas homoseksual adalah adanya tindakan persetubuhan yang dilakukan antara individu sesama jenis.

${ }^{4}$ John Court, "Homosexuality," dalam The Complete Book of Everyday Christianity: An A-to-Z Guide to Following Christ in Every Aspect of Life, ed. Robert Banks dan R. Paul Stevens (Downers Grove: InterVarsity, 1997), 502. Aktivitas homoseksual yang sering dicatat adalah aktivitas homoseksual yang dilakukan pada zaman Yunani kuno antara
} 
Di dalam Alkitab juga terdapat larangan bagi kaum Isreal untuk tidak melakukan persetubuhan dengan sesama jenis seperti yang dilakukan bangsa kafir di sekitar mereka. ${ }^{5}$ Perbuatan homoseksual pada zaman kuno ini tidak menunjukkan bahwa perbuatan itu dilakukan atas dasar adanya kecenderungan untuk menyukai sesama jenis seperti yang ditemukan pada zaman modern. ${ }^{6}$

Pada zaman modern, homoseksual tidak hanya dilihat sebagai aktivitas seksual semata melainkan suatu kata yang memiliki unsur sosial dan juga psikologis. Herek menyebutkan ada empat dimensi dari homoseksual, yaitu homoseksual sebagai tindakan seksual, orientasi seksual, identitas seksual, dan label komunitas. ${ }^{7}$ Yarhouse membedakan homoseksual dalam tiga tingkatan, yaitu keterta-

lain dalam ritual penyembahan dewa Yunani, ritual inisiasi menuju masa dewasa. Selain itu, sering dicatat bahwa para filsuf juga sering terlibat dalam hubungan homoseksual dengan murid yang masih remaja (Grenz, Sexual Ethics, 227-228). Selain itu, terdapat beberapa kebudayaan yang mempraktikkan tradisi homoseksual yang mengharuskan bahwa remaja laki-laki masuk dalam hubungan homoseksual dengan laki-laki yang lebih dewasa dalam masa tertentu sampai remaja tersebut memasuki usia pernikahan (Herek, "Homosexuality," 152).

${ }^{5}$ Robert A.J. Gagnon, The Bible and Homosexual Practice: Texts and Hermeneutics (Nashville: Abingdon, 2001), 110.

${ }^{6}$ Court, "Homosexuality," 502.

${ }^{7}$ Pertama, tindakan seksual artinya homoseksualitas merupakan perilaku atau tindakan persetubuhan. Kedua, orientasi seksual artinya ketertarikan yang menetap terhadap sesama jenis walaupun belum tentu ketertarikan ini akan dimanifestasikan dalam bentuk perilaku persetubuhan. Ketiga, identitas seksual artinya seseorang mengidentifikasi diri sesuai dengan ketertarikan seksualnya. Contohnya, seseorang berkata, "Saya adalah seorang homoseksual." Ini mengandung makna bahwa ketertarikan terhadap sesama jenis telah menjadi identitas dirinya. Hal ini sama seperti identifikasi diri yang dilakukan individu dengan menggunakan pekerjaan, jabatan, suku atau agama. Contohnya, "Saya orang Batak" atau "Saya Kristen." Keempat, label komunitas artinya kata "homoseksual" bisa merujuk kepada sekelompok orang yang memiliki kecenderungan menyukai sesama jenis. Setiap orang yang mengidentifikasi dirinya sebagai homoseksual cenderung akan berkumpul dengan orang-orang yang sama seperti dirinya sehingga berkembang menjadi suatu komunitas homoseksual. Menurut penulis, di Indonesia sendiri dimensi keempat ini lebih nyata dengan sebutan "kaum homoseksual" daripada hanya "homoseksual" (Herek, "Homosexuality," 151-152). rikan sesama jenis, orientasi homoseksual, dan identitas sebagai gay. ${ }^{8}$ Berbeda dengan zaman kuno yang lebih menekankan pada perilaku homoseksual yang tampak, homoseksual pada zaman modern lebih dilihat sebagai suatu kecenderungan yang muncul dari dalam diri dan secara konsisten muncul di sepanjang rentang kehidupan. ${ }^{9}$ Pada zaman modern ini, aktivitas homoseksual dilakukan karena dua orang sesama jenis yang saling mencintai dan menginginkan untuk memiliki relasi monogami sedangkan pada zaman kuno, aktivitas homoseksual hanyalah bagian dari ritual agama dan budaya.

Penelitian di bidang sains mengakui bahwa perlu adanya pembedaan antara orientasi homoseksual dan juga perilaku homoseksual. ${ }^{10}$ Orang Kristen tampaknya juga tidak bisa menutup mata terhadap hasil penemuan sains yang menyatakan realitas. ${ }^{11}$ Menurut Grenz,

${ }^{8}$ Yarhouse beranggapan bahwa perjalanan seseorang untuk menyebut diri sebagai gay sangatlah panjang. Seseorang yang memiliki ketertarikan sesama jenis belum tentu memiliki orientasi homoseksual dan seseorang yang telah memiliki orientasi homoseksual belum tentu akan menyebut dirinya sebagai gay. Ketertarikan sesama jenis yang dimaksud adalah suatu pengalaman memiliki perasaan tertarik terhadap sesama jenis. Sebagai pengalaman, maka perasaan ketertarikan tersebut hanyalah suatu perasaan sementara yang tidak bisa menjadi penentu identitas seksual seseorang. Orientasi homoseksual artinya perasaan tertarik terhadap sesama jenis yang cenderung menetap dan sangat kuat dalam waktu yang cenderung lama. Identitas sebagai gay artinya ketika seseorang mau menjadikan orientasi homoseksual sebagai identitas diri. Hal ini serupa dengan apa yang disampaikan oleh Herek (lih. Herek, "Homosexuality," 151-152) (Mark A. Yarhouse, Homosexuality and the Christian (Minneapolis: Bethany, 2010), 41-42).

\section{${ }^{9}$ Grenz, Sexual Ethics, 223.}

${ }^{10}$ Orientasi homoseksual artinya kecenderungan yang menetap untuk menyukai sesama jenis. Orientasi homoseksual bisa juga disebut sebagai kecenderungan homoseksual. Perilaku homoseksual artinya perbuatan atau tindakan homoseksual secara spesifik dalam bentuk persetubuhan. Dalam tulisan ini, perilaku homoseksual bisa juga disebut sebagai aktivitas homoseksual, tindakan homoseksual, atau perbuatan homoseksual (T. W. Jennings, "Homosexuality," dalam Dictionary of Pastoral Care and Counseling, ed. Rodney J. Hunter (Nashville: Abingdon, 1990), 529).

${ }^{11}$ Stanton L. Jones dan Mark A. Yarhouse, Homosexuality: The Use of Scientific Research in the Church's Moral Debate (Downers Grove: InterVarsity, 2000), 15-16. 
konsep homoseksual masa kini yaitu homoseksual sebagai preferensi seksual personal dan bukan hanya sebagai aktivitas seksual adalah konsep yang lebih banyak dipegang oleh etikawan Kristen dan peneliti di bidang sains pada masa kini. ${ }^{12}$

Menurut Yarhouse, jika seseorang memiliki ketertarikan secara terus-menerus terhadap sesama jenis padahal sebenarnya mereka berharap ketertarikan ini akan menghilang seiring berjalannya waktu, maka orang tersebut dapat dikatakan memiliki orientasi homoseksual. ${ }^{13}$ Herek menyatakan bahwa orang-orang dengan orientasi homoseksual tidak pernah secara sadar memilih untuk menyukai sesama jenis. Ketertarikan itu muncul dan menetap di dalam diri mereka tanpa bisa diubah. ${ }^{14}$

Faktor penyebab yang membentuk orientasi homoseksual belum dapat diketahui dengan pasti. Sebagian peneliti dan juga aktivis homoseksual meyakini bahwa faktor genetis berperan penting dalam pembentukan orientasi homoseksual. Namun, penelitian dalam bidang sains tidak mampu menunjukkan keterkaitan yang kuat bahwa faktor genetis menjadi faktor utama yang bersumbangsih penuh pada homoseksualitas manusia. ${ }^{15}$ Faktor lingkungan dan pengasuhan dianggap turut memberikan sumbangsih bagi pembentukan orientasi homoseksual. Relasi dengan orangtua di masa kecil dan ketidakhadiran

\footnotetext{
${ }^{12}$ Grenz, Sexual Ethics, 225.

${ }^{13}$ Mark A. Yarhouse, "Same Sex Attraction, Homosexual Orientation, and Gay Identity: A Three-Tier Distinction for Counseling and Pastoral Care," The Journal of Pastoral Care \& Counseling 59, no. 3 (Fall 2005): 202.

${ }^{14}$ Herek, "Homosexuality," 154.

${ }^{15}$ Contohnya penelitian yang dilakukan Bailey dan Pillard terhadap saudara kembar pada tahun 1992 memperlihatkan bahwa $52 \%$ dari saudara kembar tersebut keduanya adalah homoseksual. Penelitian ini menunjukkan indikasi bahwa faktor genetis berperan penting. Namun, timbul juga pertanyaan mengapa sisa $48 \%$ dari anak kembar yang diteliti hanya salah satu yang menjadi homoseksual sedangkan saudara kembarnya tidak (David K. Clark dan Robert V. Rakestraw, Readings in Christian Ethics, vol. 2, Issues and Applications [Grand Rapids: Baker, 1996], 180).
}

orangtua menyulitkan anak untuk melakukan identifikasi terhadap seksualitasnya sendiri. ${ }^{16}$

American Psychological Association memberikan pernyataan sehubungan dengan perdebatan mengenai faktor pembentuk orientasi homoseksual sebagai berikut:

There is no consensus among scientists about the exact reasons that an individual develops a heterosexual, bisexual, gay, or lesbian orientation. Although much research has examines the possible genetic, hormonal, developmental, social, and cultural influences on sexual orientation, no findings emerged that permit scientists to conclude that sexual orientation is determined by any particular factor or factors. Many think that nature and nurture both play complex roles; most people experience little or no sense of choice about their sexual orientation. ${ }^{17}$

Dengan demikian, dapat dikatakan bahwa konsep homoseksual masa kini memunculkan orientasi homoseksual sebagai bagian yang penting dalam keputusan untuk melakukan aktivitas homoseksual. Ini menjadikan homoseksual sebagai predisposisi yang tidak dipilih secara sadar namun muncul di dalam diri yang dapat bermanifestasi dalam bentuk perilaku.

\section{Konsep Homoseksual Masa Kini sebagai Dasar Dukungan terhadap Perilaku Seksual}

Pusat dari perjuangan para kaum pro homoseksual terletak pada konsep homoseksual sebagai orientasi yang muncul di luar kesadaran manusia. Mereka terus mendesak kalangan aktivitis HAM, pemerintah bahkan gereja untuk melihat homoseksual sebagai sesuatu yang normal, wajar dan perlu mendapatkan penerimaan penuh. ${ }^{18}$ 181.

${ }^{16}$ Clark dan Rakestraw, Readings in Christian Ethics,
${ }^{17}$ Yarhouse, Homosexuality and the Christian, 79.
${ }^{18}$ Grenz, Sexual Ethics, 227. 


\section{Karena Orientasi Homoseksual Muncul \\ Bukan atas Dasar Kemauan dan Pilihan \\ Pribadi, Berarti Perilaku yang Muncul sebagai Akibat dari Orientasi Tersebut Bisa Dibenarkan}

Kaum homoseksual beranggapan bahwa faktor genetis dan faktor lingkungan telah membentuk mereka dengan orientasi homoseksual di luar kehendak mereka. Orientasi homoseksual membuat mereka "couldn't help but behave the way they do." ${ }^{19}$ Bagi kaum homoseksual, orientasi homoseksual sebagai suatu "innate condition" adalah sesuatu yang normal dan wajar. ${ }^{20}$ Jika orientasi homoseksual mereka adalah sesuatu yang normal dan wajar, maka perilaku mereka secara alamiah juga adalah sesuatu yang normal. Jadi, tidak ada hak bagi gereja untuk menyatakan bahwa perilaku homoseksual mereka bertentangan dengan firman Tuhan.

\section{Karena Orientasi Homoseksual Berasal dari dalam Diri, Berarti Homoseksual adalah Bagian dari Rencana Allah atas Seksualitas Manusia}

Kaum pro homoseksual berpikir bahwa orientasi homoseksual sebagai sesuatu di luar kontrol mereka merupakan bagian dari penciptaan Allah. Mereka berargumentasi bahwa jika Allah menyebut manusia sebagai ciptaan yang baik (Kej. 1:31), maka orientasi homoseksual dalam diri mereka juga baik dan orientasi yang baik itu harus dipuaskan. ${ }^{21}$ James Nelson berpendapat bahwa Allah berkenan terhadap persatuan secara homoseksual sama seperti Dia berkenan terhadap persatuan heteroseksual. ${ }^{22}$ Apa yang paling dibutuhkan dalam suatu hubungan adalah kasih dan kasih ini tidak hanya dimiliki oleh kaum heterosek-

${ }^{19}$ John S. Feinberg dan Paul D. Feinberg, Ethics for a Brave New World, Ed. ke-2 (Wheaton: Crossway, 2010), 365.

${ }^{20}$ John M. Frame, The Doctrine of the Christian Life (Phillipsburg: P\&R, 2008), 262.

${ }^{21}$ Feinberg dan Feinberg, Ethics for a Brave, 308.

${ }^{22}$ Clark dan Rakestraw, Readings in Christian, 178. sual namun juga kaum homoseksual. ${ }^{23}$ Sekalipun mereka ingin mengubah orientasi menjadi heteroseksual, orientasi seksual itu sulit diubah sehingga lebih baik bagi mereka untuk menjadi homoseksual dan masuk dalam pernikahan monogami. McNeill secara terangterangan mengatakan bahwa

I opposed the view that God intends all human beings to be heterosexual. ... I proposed instead that God so created humans that they develop with a great variety of both gender identities and sexual object choices . . . it is a gift from God to be accepted and lived out with gratitude. God does not despise anything that God has created. ${ }^{24}$

\section{Alkitab Tidak Menyebutkan Mengenai Orientasi Homoseksual, Bahkan Sebenarnya Alkitab Tidak Menentang Perbuatan Homo- seksual, Jadi Homoseksual Bukanlah Dosa di Hadapan Tuhan}

Argumen yang dipakai oleh kaum pro homoseksual adalah bahwa tidak ada bagian di dalam Alkitab yang menyebutkan mengenai orientasi homoseksual. Jika orientasi homoseksual yang menjadi dasar yang mendorong seseorang untuk masuk dalam perilaku homoseksual tidak disinggung di dalam Alkitab, tentu saja tidak mungkin menganggap perilakunya sebagai sesuatu yang berdosa. ${ }^{25}$ Lebih jauh lagi mereka berpendapat bahwa perbuatan homoseksual pun sebenarnya tidak ditentang di dalam Alkitab. Argumen ini terutama muncul dari para sarjana biblika yang pro homoseksual dengan melakukan eksegesis pada bagian Alkitab yang sering dipakai untuk menentang homoseksual. Beberapa bagian Alkitab yang sering dikutip antara lain Kejadian 19, Imamat 18:22; 20:13, Roma 1:2627, 1 Korintus 6:9-11, dan 1 Timotius 1:8-10.

Salah satu yang paling terkenal adalah Kejadian 19 tentang Sodom dan Gomora. Pada

\footnotetext{
${ }^{23}$ John McNeill, "Homosexuality: Challenging the Church to Grow," dalam Homosexuality in the Church: Both Sides of the Debate, ed. Jeffrey S. Siker (Louisville: Westminster John Knox, 1994), 51.

${ }^{24}$ Ibid., 50.

${ }^{25}$ Grenz, Sexual Ethics, 228.
} 
bagian ini, Bailey mengatakan bahwa masalah Sodom dan Gomora bukanlah homoseksualitas melainkan ketidakramahan terhadap orang asing. ${ }^{26}$ Beberapa penafsir pro homoseksual lainnya juga memberikan penafsiran pada ayat ini yang intinya ingin menegaskan bahwa Alkitab tidak menentang homoseksual. ${ }^{27}$ Ayat lain yang juga mendapatkan penyesuaian oleh kaum pro homoseksual adalah Roma 1:26-28. Mereka berkata bahwa Paulus tidak mengecam homoseksualitas masa kini yang "natural." Apa yang Paulus kecam adalah orang-orang yang secara natural adalah heteroseksual namun masuk ke dalam perilaku homoseksual. ${ }^{28}$ Ayat-ayat Alkitab lainnya yang disebutkan di atas juga mendapatkan penafsiran "baru" yang lebih sesuai dengan kebutuhan kaum homoseksual namun tidak akan dibahas lebih lanjut pada tulisan ini. ${ }^{29}$

\section{Evaluasi Dukungan terhadap Homoseksual dari Sudut Pandang Biblika dan Teologis}

Alkitab tidak pernah memandang homoseksual sebagai sesuatu yang natural dan normal. Apa yang natural dan normal bagi manusia belum tentu sesuai dengan kehendak Allah. Grenz menulis "our natural inclinations are not a sure guide to proper human conduct. ..."30 Oleh karena itu, konsep-konsep dukungan terhadap homoseksual di atas akan mendapatkan evaluasi pada poin-poin berikut ini.

\footnotetext{
${ }^{26}$ Richard Dayringer, "Homosexuality Reconsidered,"
} The Journal of Pastoral Care 50 No. 1 (Spring 1996): 59.

${ }^{27}$ Contoh lainnya adalah tafsiran bahwa dosa Sodom dan Gomora bukanlah dosa homoseksual melainkan penyembahan berhala. Ada juga yang berpendapat narasi ini bukan menitikberatkan pada dosa homoseksual melainkan pada obyek tindakan homoseksual, yaitu para malaikat. Karena obyek tindakan mereka inilah yang membuat penduduk Sodom dan Gomora dihukum Allah. Tafsiran lain menyatakan bahwa dosa Sodom dan Gomora adalah ketidakramahan terhadap orang asing (Feinberg dan Feinberg, Ethics for a Brave, 315-319).

${ }^{28}$ Clark dan Rakestraw, Readings in Christian, 203.

${ }^{29}$ Untuk lebih mendalami eksegesis dan pro kontra terhadap bagian firman Tuhan ini dapat membaca The Bible and Homosexual Practice: Texts and Hermeneutics karangan Robert A.J. Gagnon dan Ethics for a Brave New World karangan John S. Feinberg dan Paul D. Feinberg.

${ }^{30}$ Grenz, Sexual Ethics, 230.

\section{Orientasi Homoseksual Tidak Membenar- kan Perilaku Homoseksual}

Walaupun seseorang tidak bisa memilih untuk memiliki orientasi homoseksual atau heteroseksual, ini tidak menyebabkan individu tersebut melepaskan diri dari tanggung jawab atas tindakan yang akan diambilnya. ${ }^{31}$ Seseorang yang memiliki orientasi homoseksual tidak harus menjadi seorang homoseksual. Walaupun kecenderungan itu ada di dalam dirinya, tidak berarti bahwa kecenderungan itu harus diikuti. $^{32}$ Jika memang benar bahwa orientasi homoseksual diturunkan secara genetis, hal itu tetap tidak menghapus tanggung jawab manusia dalam berperilaku. ${ }^{33}$ Jones memberikan gambaran mengenai tanggung jawab perilaku homoseksual dengan membandingkannya dengan pecandu alkohol: Just as a person (due to environmental and possible hereditary factors) with a tendency toward alcoholism should not drink alcohol beverages, so a homosexually oriented person needs to refrain from homosexual activities. ${ }^{34}$

Manusia memiliki akal budi dan pikiran yang bisa digunakannya untuk memilih melakukan suatu perbuatan atau tidak. Allah memang berdaulat penuh atas kehidupan manusia, namun itu tidak melepaskan manusia dari tanggung jawab atas segala tindakannya. ${ }^{35}$ Kecenderungan dari dalam diri manusia tidak menjadikan standar moral dalam diri Allah berubah. Manusia memiliki tanggung jawab untuk taat pada perintah Allah dan pada standar Allah. ${ }^{36}$ Feinberg berkata bahwa "humans . . . are morally accountable when they choose to disobey God's rules." ${ }^{37}$ Larangan Allah yang paling jelas mengenai perilaku homoseksual ada di dalam Imamat 18:22, "Janganlah engkau tidur dengan laki-laki secara orang bersetubuh dengan perempuan, karena itu

\footnotetext{
${ }^{31}$ Clark dan Rakestraw, Readings in Christian, 181-182.

${ }^{32}$ Feinberg dan Feinberg, Ethics for a Brave, 365.

${ }^{33}$ Ibid.

${ }^{34}$ Clark dan Rakestraw, Readings in Christian, 181-182.

${ }^{35}$ Frame, The Doctrine, 837.

${ }^{36}$ Ibid., 810.

${ }^{37}$ Feinberg dan Feinberg, Ethics for a Brave, 384.
} 
suatu kekejian." Allah dengan jelas melarang bangsa Israel untuk melakukan tindakan homoseksual dengan tujuan menjaga kekudusan bangsa Israel. Sebagai ciptaan yang diciptakan Allah sesuai dengan gambar dan rupa-Nya, manusia memiliki tanggung jawab untuk bertindak sesuai dengan karakter Allah, yaitu kebenaran dan kekudusan. ${ }^{38}$

Perilaku homoseksual adalah perilaku yang bertentangan dengan kekudusan Allah sehingga tidak mungkin perilaku ini bisa dibenarkan. Orientasi homoseksual walaupun timbul di luar kontrol manusia tidak bisa dijadikan alasan melepaskan diri dari tanggung jawab untuk melakukan perbuatan yang sesuai dengan kehendak Allah. Sebagai representasi Allah di dalam dunia, manusia seharusnya bertindak di dalam standar kekudusan Allah dan perilaku homoseksual jelasjelas berlawanan dengan standar Allah.

\section{Homoseksual Bukanlah Rancangan Ideal Allah bagi Seksualitas Manusia}

Memang orientasi homoseksual muncul dari dalam diri manusia dan kemunculannya juga bukan sesuatu yang dipilih dan disadari, namun hal ini tidak menunjukkan bahwa homoseksual adalah rancangan Allah bagi manusia. Allah tidak menciptakan hasrat homoseksual dan menyebutnya sebagai sesuatu yang baik, bahkan pada faktanya hasrat yang baik sekalipun tidak harus mendapatkan gratifikasi langsung. ${ }^{39}$ Allah tidak pernah merancangkan sesuatu yang berlawanan dengan karakter-Nya, yaitu kekudusan. Rancangan ideal Allah atas seksualitas manusia diingatkan kembali oleh Yesus ketika orang Farisi bertanya mengenai perceraian (Mat. 19:1-12). Yesus mengacu kembali kepada

\footnotetext{
${ }^{38}$ Frame, The Doctrine, 809.

${ }^{39}$ Frame menyebutkan bahwa hasrat seksual (sexual desire) sebagai sesuatu yang baik yang diberikan Allah dalam pernikahan dan untuk reproduksi. Seorang single yang memiliki hasrat seksual terhadap orang lain yang menjadi calon pengantinnya tidak dapat dikatakan berdosa namun memang harus menantikan sampai pada pernikahannya untuk mewujudkan hasrat seksualnya dalam aktivitas seksual (Frame, The Doctrine, 767). Untuk pemahaman mengenai gratifikasi lih. Jones dan Yarhouse, Homosexuality: The Use of Scientific, 18.
}

penciptaan yang dilakukan Allah dalam Kejadian 2.

Allah menciptakan laki-laki pertama, yaitu Adam dan kemudian menciptakan seorang penolong bagi Adam, yaitu seorang perempuan (Hawa). Allah menciptakan perempuan dan bukan laki-laki lain untuk menjadi penolong bagi Adam membuktikan bahwa apa yang Allah inginkan pada mulanya adalah persatuan heteroseksual dan bukan homoseksual. ${ }^{40}$ Penciptaan laki-laki dan perempuan ini adalah rancangan ideal Allah sebelum manusia jatuh dalam dosa dan ini yang harus menjadi acuan utama bagi manusia masa kini dalam hal seksualitas dan perilaku seksual. ${ }^{41}$ Selain itu, Allah juga menciptakan laki-laki dan perempuan dengan organ reproduksi yang saling melengkapi untuk mampu melaksanakan perintah prokreasi (Kej. 1:28). Mandat ini tidak akan mampu dilakukan secara alamiah oleh pasangan homoseksual karena mereka tidak memiliki organ reproduksi yang saling melengkapi seperti pada pasangan heteroseksual. ${ }^{42}$ Frame berkata bahwa homoseksual melawan kehendak Allah atas seks dan pernikahan sebab di dalam Alkitab, hubungan seksual selalu dilakukan oleh satu laki-laki dan perempuan di dalam pernikahan. ${ }^{43}$ Dengan kata lain bahwa setiap hasrat untuk melakukan hubungan seksual bahkan oleh kaum heteroseksual sekalipun hanya boleh dimanifestasikan dalam lembaga pernikahan.

\section{Alkitab dengan Jelas Menentang Perilaku Homoseksual}

Alkitab memang tidak secara eksplisit berbicara mengenai orientasi homoseksual, namun tidak berarti Alkitab tidak menentang perilaku homoseksual. Setiap bagian Alkitab yang mencatat mengenai perilaku homoseksual jelas-jelas menyebut tindakan tersebut sebagai kekejian (Im. 18:22) dan orang-orang

\footnotetext{
${ }^{40}$ Feinberg dan Feinberg, Ethics for a Brave, 357.

${ }^{41}$ Yarhouse, Homosexuality and the Christian, 19.

${ }^{42}$ Feinberg dan Feinberg, Ethics for a Brave, 357-358.

${ }^{43}$ Frame, The Doctrine, 759.
} 
yang melakukannya tidak akan mendapat bagian dalam kerajaan Allah (1Kor. 6:9-11).

Secara khusus di dalam Kejadian 19, Alkitab jelas-jelas berbicara mengenai perilaku homoseksual penduduk Sodom dan Gomora. Penafsiran tradisional yang selama ini telah dipakai menyatakan bahwa penduduk lakilaki Sodom dan Gomora hendak mempraktikkan tindakan homoseksual kepada para tamu Lot. Kata Yâda' (Kej. 19:5) yang dipakai memiliki makna hubungan seksual. ${ }^{44}$ Menurut Feinberg, ketika Lot menawarkan kedua anak gadisnya (Kej. 19:8) kepada penduduk Sodom dan Gomora, kata yâda' jelas mengandung makna seksual sehingga tidak masuk akal jika satu kata yang sama yang dipakai dalam keseluruhan narasi memiliki dua makna yang berbeda. ${ }^{45}$

Paulus dalam Roma 1:26-28 juga secara jelas mengecam perilaku homoseksual sebagai persetubuhan yang tidak wajar. Wajar ( $p h u-$ sikos dalam bahasa Inggris natural) yang dimaksudkan oleh Paulus adalah wajar sesuai dengan desain awal Allah dalam struktur penciptaan manusia. ${ }^{46}$ Jika demikian, tindakan homoseksual adalah tindakan bertentangan dengan desain Allah atas seksualitas manusia sehingga sangat tepat bagi Paulus untuk mengatakannya sebagai perilaku yang tidak wajar (Rm. 1:26).

Secara keseluruhan, dapat dilihat bahwa tidak ada satu bagian pun baik secara biblika maupun secara teologis yang mendukung perilaku homoseksual. Perilaku homoseksual walaupun timbul dari orientasi dari dalam diri tidaklah dapat dibenarkan dan bukanlah rancangan Allah sebab di dalam Alkitab, jelas bahwa Allah sendiri melarang aktivitas homoseksual terjadi dalam umat-Nya yang kudus.

\section{Apakah Homoseksual adalah Dosa?}

Pertanyaan ini akan sangat mudah dijawab jika konsep homoseksual yang dipegang masih konsep yang hanya melihat homosek-

\footnotetext{
${ }^{44}$ Dayringer, "Homosexuality Reconsidered," 59.

${ }^{45}$ Feinberg dan Feinberg, Ethics for a Brave, 314.

${ }^{46}$ Ibid., 336.
}

sual sebagai tindakan seksual semata. Sesuai dengan firman Tuhan, tentu saja homoseksual adalah tindakan yang berdosa di hadapan Tuhan (hal ini juga telah jelas dipaparkan di bagian ketiga dari tulisan ini). Namun, jika meninjaunya dari sudut konsep homoseksual masa kini, orientasi homoseksual menjadi suatu "ganjalan" yang sulit untuk dijelaskan. Tentunya kita harus berhati-hati dan berhikmat ketika memberi label "berdosa" kepada kaum homoseksual yang benar-benar ingin mengasihi Tuhan, berusaha menaati perintah-Nya dan terus bergumul dengan orientasi homoseksual yang tidak diinginkannya. ${ }^{47}$

Frame menjelaskan orientasi dalam dua bentuk, yaitu sebagai godaan (temptation) dan juga sebagai hawa nafsu (lust). ${ }^{48}$ Jika orientasi homoseksual itu muncul sebagai godaan yang datang dari luar diri individu tersebut, maka ini bukanlah dosa karena setiap orang pasti mengalami godaan. Namun, jika orientasi homoseksual memunculkan hawa nafsu di dalam diri untuk melakukan tindakan yang tidak berkenan di hadapan Allah, maka ini dapat disebut sebagai dosa. Setiap individu tanpa terkecuali memiliki titik lemah yang dapat dimanfaatkan oleh iblis untuk menarik kita jatuh ke dalam tindakan yang berdosa. ${ }^{49}$ Bagi sebagian orang, titik lemah ini terletak pada orientasi seksualnya. Walaupun Frame memberikan perbedaan dalam pemahamannya terhadap orientasi, dalam praktiknya sulit sekali untuk menarik garis batas antara godaan dan hawa nafsu sebab keduanya dengan sangat mudah bercampur dalam hati manusia yang berdosa.

Pembahasan mengenai orientasi homoseksual manusia juga tidak bisa terlepas dari kejatuhan manusia ke dalam dosa. Kejatuhan manusia ke dalam dosa menyebabkan terjadinya penyimpangan dari apa yang dirancangkan Allah pada mulanya. Masuknya dosa ke dalam dunia menyebabkan manusia harus mengalami penderitaan, sakit penyakit, dan

\footnotetext{
${ }^{47}$ Yarhouse, Homosexuality and the Christian, 35.

${ }^{48}$ Frame, The Doctrine, 760

${ }^{49}$ Ibid., 264.
} 
juga kematian. Orientasi homoseksual juga merupakan salah satu akibat yang muncul dari kejatuhan manusia dalam dosa. ${ }^{50}$ Grenz menggambarkan dimensi dosa dari orientasi homoseksual sebagai berikut:

Although the homosexual orientation is not God's ideal, this conclusion does not mean that the disposition itself is condemnable. ... the condemnation of God rests not on human dispositions themselves, even though they participate in human fallenness, but on actions that flow from them. In the case of homosexuality, the tendency to be erotically aroused by members of the same sex, while potentially dangerous and placing the person at certain disadvantages, does not itself invoke the condemnation of God. Sin as the transgression ... occurs ... when this disposition is allowed to express itself in actions. ${ }^{51}$

Sebagai manusia yang telah jatuh dalam dosa, seksualitas kita juga mengambil bagian di dalam kejatuhan tersebut. Hal ini mengakibatkan orientasi heteroseksual yang pada awalnya merupakan rancangan Allah menjadi terdistorsi. Sebagai manusia yang memiliki "sinful nature" maka orientasi homoseksual mengambil bagian di dalam keberdosaan manusia sebab "sinful nature is ours even from conception." "52 Namun, jika dosa dipahami sebagai perilaku manusia yang tidak sesuai dengan standar moral Allah, maka orientasi homoseksual di dalam dirinya sendiri belum dapat dikatakan sebagai dosa karena belum tercetus dalam tindakan. ${ }^{53}$

\footnotetext{
${ }^{50}$ Feinberg dan Feinberg, Ethics for a Brave, 383.

${ }^{51}$ Grenz, Sexual Ethics, 233.

${ }^{52}$ John M. Frame, Systematic Theology: An Introduction to Christian Belief (Phillipsburg: P\&R, 2013), 860.

${ }^{53}$ Grenz, Sexual Ethics, 232.
}

\section{Penutup}

Konsep homoseksual masa kini diakui memberikan kesulitan tersendiri untuk memberikan jawaban terhadap pergumulan etis yang berkaitan dengan homoseksualitas. Namun demikian, otoritas yang tertinggi adalah firman Tuhan dan sebagai orang yang tunduk di bawah firman Tuhan, kita harus mengikuti apa yang menjadi pernyataan Allah di dalam firman-Nya, yaitu melihat homoseksual secara utuh sebagai perilaku yang berdosa yang di dalamnya juga terdapat orientasi yang terdistorsi karena kejatuhan manusia dalam dosa. Firman Tuhan juga menjadi standar moral bagi umat percaya sehingga homoseksual tidak dapat dibenarkan secara moral.

Walaupun demikian, homoseksual bukanlah dosa yang tidak dapat diampuni oleh Allah. Allah menyediakan pengampunan bagi setiap orang yang datang kepada-Nya dan mengakui dosanya (1Yoh. 1:9). Allah juga akan menyediakan kekuatan untuk memenangkan pergumulan melawan hasrat orientasi homoseksualnya yang terus-menerus meminta untuk dipuaskan dalam bentuk perilaku (1Kor. 10:13) dan pada saatnya nanti kita akan dibebaskan dari tubuh yang fana ini kepada tubuh kemuliaan (Rm. 8:21-23). 


\section{Daftar Kepustakaan}

Clark, David K., dan Robert V. Rakestraw. Readings in Christian Ethics. Vol. 2, Issues and Applications. Grand Rapids: Baker, 1996.

Court, John "Homosexuality." Dalam The Complete Book of Everyday Christianity: An A-to-Z Guide to Following Christ in Every Aspect of Life. Diedit oleh Robert Banks dan R. Paul Stevens, 501-505. Downers Grove: InterVarsity, 1997.

Dayringer, Richard. "Homosexuality Reconsidered," The Journal of Pastoral Care 50 no. 1 (Spring 1996): 57-71.

Feinberg, John S., dan Paul D. Feinberg. Ethics for a Brave New World. Ed. ke-2. Wheaton: Crossway, 2010.

Frame, John M. The Doctrine of the Christian Life. Phillipsburg: P\&R, 2008. . Systematic Theology: An Introduction to Christian Belief . Phillipsburg: P\&R, 2013.

Gagnon, Robert A. J. The Bible and Homosexual Practice: Texts and Hermeneutics. Nashville: Abingdon, 2001.

Grenz, Stanley J. Sexual Ethics: An Evangelical Perspective. Louisville: Westminster John Knox, 1990.

Herek, G. M. "Homosexuality.” Dalam Encyclopedia of Psychology. Vol.2. Ed. ke-2. Diedit oleh Raymond J. Corsini, 151-155. Toronto: John Wiley \& Sons, 1994.

Jennings, T. W. "Homosexuality." Dalam Dictionary of Pastoral Care and Counseling. Ed. Roney J. Hunter, 529-532. Nashville: Abingdon, 1990.

Johnson, Malcolm "Homophobia." Dalam The New Dictionary of Pastoral Studies. Diedit oleh Wesley Carr et al., 156-157. Grand Rapids: Eerdmans, 2002.

Jones, Stanton L., dan Mark A. Yarhouse. Homosexuality: The Use of Scientific Research in the Church's Moral Debate. Downers Grove: InterVarsity, 2000.

McNeill, John. "Homosexuality: Challenging the Church to Grow." Dalam Homosexuality in the Church: Both Sides of the Debate. Diedit oleh Jeffrey S. Siker, 49-58. Louisville: Westminster John Knox, 1994.

Yarhouse, Mark A. Homosexuality and the Christian. Minneapolis: Bethany, 2010.

. "Same Sex Attraction, Homosexual Orientation, and Gay Identity: A Three-Tier Distinction for Counseling and Pastoral Care." The Journal of Pastoral Care \& Counseling 59, no. 3 (Fall 2005): 201-211. 